RASĀYAN J. Chem.

Vol. 13 | No. 4 |2559-2568| October - December | 2020 ISSN: 0974-1496 | e-ISSN: 0976-0083 | CODEN: RJCABP

\title{
MOLECULAR MODELING, SYNTHESIS, AND QSAR OF 5-O-ACYLPINOSTROBIN DERIVATIVES AS PROMISING ANALGESIC AGENT
}

\author{
Siswandono $^{1}$, Retno Widyowati ${ }^{2}$, Andi Suryadi ${ }^{2,3}$, Tri Widiandani ${ }^{1 *}$, \\ and Deka Prismawan ${ }^{4}$ \\ ${ }^{1}$ Department of Pharmaceutical Chemistry, Faculty of Pharmacy, Universitas Airlangga, \\ Surabaya, 60115, Indonesia. \\ ${ }^{2}$ Department of Pharmacognosy and Phytochemistry, Faculty of Pharmacy, Universitas \\ Airlangga, Surabaya, 60115, Indonesia. \\ ${ }^{3}$ Department of Pharmacy, Faculty of Sport and Health, Universitas Negeri Gorontalo, \\ Gorontalo, 96128, Indonesia. \\ ${ }^{4}$ Department of Pharmacy, School of Medicine and Health Sciences, Universitas Katolik \\ Indonesia Atma Jaya, Jakarta, 14440, Indonesia. \\ *E-mail: tri-w@ff.unair.ac.id
}

\begin{abstract}
Pain remains a major healthcare problem nowadays, despite the recent advances and knowledge about its mechanism and management. Currently marketed analgesics and NSAIDs include both non-selective COX inhibitors and selective COX-2 inhibitors exhibit several disadvantages such as increasing gastrointestinal bleeding and cardiovascular risk. We aimed to develop a potential analgesic by utilizing structural modifications on pinostrobin, which is previously known to possess anti-inflammatory properties. Schotten-Baumann esterification reaction was employed to produce four 5-O-acylpinostrobin derivatives, namely pinostrobin acetate, pinostrobin propionate, pinostrobin butyrate, and pinostrobin pentanoate, with moderate to good yields (61-84\%). The acetic acid-induced writhing test using Mus musculus was demonstrated to evaluate the analgesic activity of the compounds. 5-O-Acylpinostrobin derivatives display some improvements in analgesic activity compared to pinostrobin itself. Pinostrobin pentanoate emerges as the most potent compound with an $\mathrm{ED}_{50}$ value of $10.37 \mathrm{mg} / \mathrm{kg} \mathrm{BW}$. This result is consistent with the in silico study which we performed before the synthesis. The structural modification of pinostrobin is successful in improving the analgesic potency, resulting in pinostrobin pentanoate as the optimum compound. Furthermore, the increasing analgesic potency is in line with the increasing length of the side alkyl chain, suggesting the importance of the steric parameter in the QSAR formulation which can be invoked as a predictive tool for future optimization.

Keywords: Molecular Modeling, Synthesis, 5-O-acylpinostrobin Derivatives, Analgesic, QSAR
\end{abstract}

(C) RASĀYAN. All rights reserved

\section{INTRODUCTION}

Despite the increasing developments and knowledge in the past four decades about the mechanisms and management, the pain remains a major healthcare problem in the modern era. Global estimation suggests that each year, $20 \%$ of adults experience pain and another $10 \%$ of adults are diagnosed with chronic pain. ${ }^{1}$ In general, pain is classified into either acute or chronic. Normally, acute pain is a sign of potential tissue damage, a result of accidental injury, inflammation, or surgery. While most acute pain is readily managed, however, it can progress into chronic pain if appropriate management was not provided. ${ }^{1,2}$ It is well established that many pathological pain states are due to the inflammatory responses in the peripheral and central nervous systems. ${ }^{3}$ Therefore, many scientific researchers also focus on inflammation since it usually involves pain and oedema as a result of the release of many pro-inflammatory mediators at the site of injury. ${ }^{4}$ The serious implications of pain such as depression, inability to do a normal activity, disrupted social life, and suicidal thoughts, ${ }^{1}$ have led to an enormous discovery effort for alternative analgesics and 
RASĀYAN J. Chem.

Vol. 13 | No. 4 |2559-2568| October - December | 2020

anti-inflammatory agents or non-steroidal anti-inflammatory drugs (NSAIDs), since many of the existing NSAIDs cause several adverse effects due to their non-selective inhibition of both cyclooxygenases (COX1 and COX-2). ${ }^{5}$ COX-1 enzyme plays an important role in the synthesis of prostaglandins, key mediators which are involved in inflammation. Unfortunately, these prostaglandins also act as a gastric mucosal protective agent. Inhibition of this enzyme as part of pain management may lead to ulceration as a consequence. ${ }^{6}$ On the other hand, by selectively inhibiting COX-2 in pain management, the risk of upper gastrointestinal bleeding is reduced by $50-60 \%$ when compared to non-selective COX inhibition. ${ }^{7,8}$ However, the use of currently marketed selective COX-2 inhibitors such as rofecoxib, celecoxib, and valdecoxib increases the risk of cardiovascular events. ${ }^{9}$ Therefore, the development of selective COX-2 inhibitors is still of great interest to overcome the complication in pain management.

In this study, we investigated and developed an alternative analgesic, starting with pinostrobin as the lead compound. Pinostrobin is a flavonoid found as one of the major components in the rhizome of Curcuma rotunda.$^{10}$ It is also found in Boesenbergia pandurata (Roxb.) Schlechter, a medicinal and culinary herb that grows abundantly in the tropical rain forest of Southeast Asia. ${ }^{11}$ Several studies showed that pinostrobin possesses various pharmacological benefits, including antioxidant activity, antimicrobial activity, antifungal activity, and anti-inflammatory activity. ${ }^{12}$ A study conducted by Gomez-Betancur et al. suggested that pinostrobin demonstrates analgesic and anti-inflammatory properties and might have a mechanism of action similar to NSAIDs such as ibuprofen, by inhibiting cyclooxygenase (COX). ${ }^{13}$ However, it displays a poor inhibitory activity against COX-1 and COX-2 at a concentration of 100 $\mu \mathrm{g} / \mathrm{mL} .^{14}$ Thus, we investigated the possibility of an improved potency by performing molecular modifications, in which we employed esterification of the hydroxy group of pinostrobin using SchottenBaumann reaction.<smiles>COc1cc(O)c2c(c1)OC(c1ccccc1)CC2=O</smiles>

Fig.-1: The Structure of Pinostrobin

\section{EXPERIMENTAL}

\section{Material and Methods}

The molecular structure of cyclooxygenase-2 receptors with ligand diclofenac (DIF_701), PDB ID: 1PXX, can be downloaded via a protein data bank site. The $2 \mathrm{D}$ structure of the $5-O$-acylpinostrobin derivatives was drawn using the ChemBioDraw Ultra version 12 (Cambridge Soft) and then copied into the ChemBio3D Ultra version 12, to create the 3D structure and measure its minimum energy using MMFF94, and then stored as .mol2.

\section{Chemistry}

General Methods. All reagents were purchased from Sigma-Aldrich, Merck, and Dexa Medica without purification unless otherwise stated. All solvents were reagent-grade. Reactions were monitored by thinlayer chromatography (TLC) on silica gel 60/ Kieselguhr 254 (Merck). Melting points were measured on Melt Temp Electrothermal Melting Point Apparatus, NMR spectra were recorded on JEOL ICS $400 \mathrm{MHz}$ spectrometer at $25^{\circ} \mathrm{C}$. Chemical shift $(\delta)$ is reported in ppm relative to the residual solvent peak using tetramethylsilane (TMS) as the internal standard. Mass spectra were recorded using GC/MS Agilent 6890 spectrometers. FT-IR spectra were recorded on the Perkin Elmer Spectrum One FTIR spectrophotometer.

\section{Docking Protocol}

The docking study of these compounds on the cyclooxygenase-2 receptor (1PXX) was conducted using Molegro Virtual Docker version 5.5. (CLCBio). The best docking results can be detected visually by comparing the structure of the docked molecules with the crystal structure of the reference ligand diclofenac (DIF_701) in the binding site (cavity 4). The results are presented as rerank scores. The lowest energy indicates the best binding pose between the functional group of the ligand and the amino acid residue of the 
RASĀYAN J. Chem.

Vol. 13 | No. 4 |2559-2568| October - December | 2020

protein. The state of the environment of each compound derivative, such as hydrogen bonds, and steric interactions was determined.

\section{Procedure for the Isolation of Pinostrobin (1)}

Temu kunci (Boesenbergia pandurata Roxb. Schlecht) rhizomes were washed with running water, then the rhizomes were cut into small pieces and dried using the oven at $50^{\circ} \mathrm{C}$. The dried rhizomes were then finely powdered, weighed, and extracted. Gradually, $2 \mathrm{~kg}$ of dried powder was extracted with $20 \mathrm{~L}$ of $n$-hexane by maceration ( 3 times). The solvent residue was evaporated under reduced pressure until $1 / 3$ of the initial volume. Recrystallisation to obtain the crystalline isolate was performed by dissolving the crude in hot methanol, then it was cooled in the refrigerator for 24 hours until the crystal formed. The crystal was washed with hot methanol 4 times, then dried in the oven at $50^{\circ} \mathrm{C}$ to obtain pinostrobin $\mathbf{1}$, as a white crystalline (38.7 gram, 1.94\% w/w). ${ }^{1} \mathrm{H}-\mathrm{NMR}\left(400 \mathrm{MHz}, \mathrm{CDCl}_{3}\right)$ : $12.03(s, 1 \mathrm{H}) ; 7.42(\mathrm{~m}, 6 \mathrm{H}) ; 6.07(d, J=3.2,2 \mathrm{H})$; $5.39(d d, J=12.8,3.2,1 \mathrm{H}) ; 3.80(s, 3 \mathrm{H}) ; 3.07(d d, J=17.2,12.8,1 \mathrm{H}) ; 2.81(d d, J=17.2,3.2,1 \mathrm{H}) .{ }^{13} \mathrm{C}-$ NMR (400 MHz, $\left.\mathrm{CDCl}_{3}\right)$ : 195.89 (C); 168.07 (C); 164.23 (C); $162.88(\mathrm{C}) ; 138.46(\mathrm{C}) ; 128.99(\mathrm{CH}) ; 126.25$ $(4 \mathrm{CH}) ; 103.23(\mathrm{C}) ; 95.23(\mathrm{C}) ; 94.38(\mathrm{CH}) ; 79.33(\mathrm{CH}) ; 55.81\left(\mathrm{CH}_{3}\right) ; 43.48\left(\mathrm{CH}_{2}\right) . m / z$ for $\left(\mathrm{C}_{16} \mathrm{H}_{14} \mathrm{O}_{4}\right)$ 270.09 , found 270.1 .

\section{Procedure for the Synthesis of Pinostrobin Derivatives (GP-A).}

A solution of pinostrobin $1(11 \mathrm{mmol}, 1.0$ equiv. $)$ in tetrahydrofuran $(10 \mathrm{~mL})$ was cooled down to $0^{\circ} \mathrm{C}$, after which a solution of the corresponding aliphatic acyl chlorides ( $35 \mathrm{mmol}, 3.2$ equiv.) in tetrahydrofuran (10 $\mathrm{mL}$ ) was added dropwise while the mixture was stirred. After that, triethylamine (62 mmol, 5.6 equiv.) was added and the mixture was stirred and let stand at room temperature for 30 minutes. Upon completion, the solvent was evaporated under reduced pressure. To the crude, hot methanol was added slowly to dissolve completely, then the solution was filtered. The filtrate was allowed to cool down to room temperature and stored in the refrigerator for 24 hours. The formed crystal was washed with methanol and filtered, then dried in an oven at $50^{\circ} \mathrm{C}$.

\section{Writhing Test Procedure}

The experimental mice (Mus musculus) were classified into three groups consisting of the positive control group, negative control group and test group. Each group consisted of five mice. For the negative control group, each mouse was injected intraperitoneally with CMC-Na $0.5 \%$. Sodium diclofenac was given in CMC-Na $0.5 \%$ with a given dose of $14 \mathrm{mg} / \mathrm{kg} \mathrm{BW}$ and was used as a reference drug. ${ }^{15}$ For the test group, each mouse was injected intraperitoneally with the test compounds in CMC-Na $0.5 \%$ with three given doses of 14,28 , and $56 \mathrm{mg} / \mathrm{kg} \mathrm{BW}$. After 30 minutes, to all groups, each mouse was injected with a solution of acetic acid $0.6 \%$ with a dose of $10 \mathrm{~mL} / \mathrm{kg} \mathrm{BW}$ as a pain inducer. The writhing reaction was observed in each group within 30 minutes after pain induction. The percentage of pain inhibition was calculated using the following formula:

$$
\% \text { Pain Inhibition }=\frac{(W c-W t)}{W c} \times 100
$$

Where, $\mathrm{Wc}=$ number of writhes in the negative control group, $\mathrm{Wt}=$ number of writhes in the test group. The results of the writhing test of pinostrobin and its derivatives are shown below. The Levene statistic test was performed to examine the homogeneity between treatments (homogeneity of variance). One-way ANOVA analysis was used with a confidence level of $95 \%(\alpha)=0,05$ to assess the significance of analgesic activity between the compounds. The half-maximal effective dose $\left(\mathrm{ED}_{50}\right)$ of each compound was calculated with probit analysis using the SPSS program.

\section{Docking}

\section{RESULTS AND DISCUSSION}

Four aliphatic acyl chlorides were selected for the esterification of pinostrobin, such as acetyl chloride, propionyl chloride, butyryl chloride, and pentanoyl chloride, to maintain the log P below five (obeying one of Lipinski's rules). Before the synthesis, we performed a docking study with the COX-2 receptor (PDB: 1PXX) using Molegro Virtual Docker v5.5 to predict the potencies of pinostrobin and its derivatives. The docking study of pinostrobin (1) shows two hydrogen bonds are formed between the oxygen in the carbonyl 
RASĀYAN J. Chem.

Vol. 13 | No. 4 |2559-2568| October - December | 2020

group and Tyr355, and between the phenolic oxygen and Ser353. Besides, four steric interactions were also observed between pinostrobin and the receptor, involving three amino acids (Leu352, Phe518, Val523) around the substituted aromatic ring, while Tyr355 interacts sterically with the phenolic oxygen (Fig.-2).

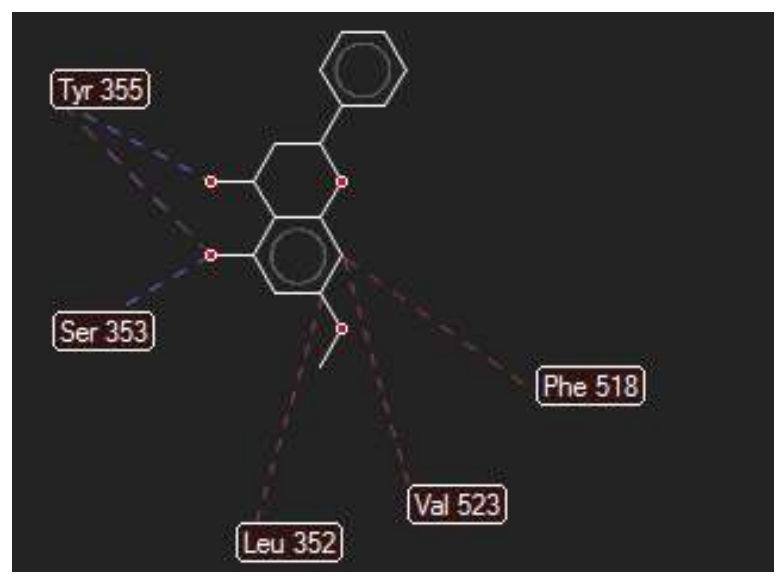

Fig.-2: The Interactions between Pinostrobin and the Receptor 1PXX as shown in the Docking Study

The hydrogen bonds and steric interactions are also found in the docking study of 5-O-acylpinostrobin derivatives. In pinostrobin acetate (2), the hydrogen bonds are present between etheric oxygen and Tyr355, and also between the oxygen carbonyl of the ester and Arg120. The steric interactions are also present involving Ser353, Ala527, Leu352, and Met522. Additionally, the docking between the other 5-Oacylpinostrobin derivatives, including pinostrobin propionate (3), pinostrobin butyrate (4), pinostrobin pentanoate (5) and the receptor shows similar hydrogen bonds and steric interaction patterns, involving Tyr 355, Arg120, Ala527, Leu352, and Met522 (figure 3). Furthermore, to predict the affinity between the compound and the receptor, we assess the value of the rerank score. Interestingly, the longer the alkyl chain of the ester, the lower the rerank score, resulting in pinostrobin pentanoate (5) having the optimum affinity with a rerank score of $-107.59 \mathrm{kcal} / \mathrm{mol}$ compared to pinostrobin with a rerank score of $-87.18 \mathrm{kcal} / \mathrm{mol}$.

\section{Synthesis of 5-O-acylpinostrobin Derivatives}

With the docking information, we set out to synthesize 5-O-acylpinostrobin derivatives by SchottenBaumann esterification. Pinostrobin was obtained by extraction of the dried rhizome of Boesenbergia pandurata (Roxb.) Schlechter, the best source for the isolation of pinostrobin. ${ }^{16}$ The Schotten-Baumann esterification reaction was performed on the phenolic group of pinostrobin, in which we reacted with the corresponding aliphatic acyl chlorides in tetrahydrofuran (THF) under basic conditions, to yield four 5-Oacylpinostrobin derivatives (2-5).

\section{7-methoxy-4-oxo-2-phenylchroman-5-yl acetate (2)}

This compound was synthesized according to $G P-A$, starting with acetyl chloride. The crude was purified and crystallized to afford the product as a white crystalline with $84 \%$ yield. M.p. $146-147^{\circ} \mathrm{C} .{ }^{1} \mathrm{H}-\mathrm{NMR}(400$ $\left.\mathrm{MHz}, \mathrm{CDCl}_{3}\right): 7.41(m, 5 \mathrm{H}) ; 6.43(d, J=2.8,1 \mathrm{H}) ; 6.28(d, J=2.8,1 \mathrm{H}) ; 5.45(d d, J=13.6,2.4,1 \mathrm{H}) ; 3.81$ $(s, 3 \mathrm{H}) ; 3.02(d d, J=16.4,13.6,1 \mathrm{H}) ; 2.74(d d, J=16.4,2.4,1 \mathrm{H}) ; 2.38(s, 3 \mathrm{H}) .{ }^{13} \mathrm{C}-\mathrm{NMR}(400 \mathrm{MHz}$, $\left.\mathrm{CDCl}_{3}\right): 188.93(\mathrm{C}) ; 169.69(\mathrm{C}) ; 165.59(\mathrm{C}) ; 164.34(\mathrm{C}) ; 151.94(\mathrm{C}) ; 138.48(\mathrm{C}) ; 128.98(\mathrm{CH}) ; 126.27(4$ $\mathrm{CH}) ; 108.03(\mathrm{C}) ; 104.88(\mathrm{CH}) ; 99.63(\mathrm{CH}) ; 79.67(\mathrm{CH}) ; 55.93\left(\mathrm{CH}_{3}\right) ; 45.15\left(\mathrm{CH}_{2}\right) ; 21.25\left(\mathrm{CH}_{3}\right) . \mathrm{m} / \mathrm{z}$ for $\left(\mathrm{C}_{18} \mathrm{H}_{16} \mathrm{O}_{5}\right) 312.32$, found 312.1 .

\section{7-methoxy-4-oxo-2-phenylchroman-5-yl propionate (3)}

This compound was synthesized according to $G P-A$, starting with propanoyl chloride. The crude was purified and crystallized to afford the product as a white powder with a $74 \%$ yield. M.p. $121-122^{\circ} \mathrm{C} .{ }^{1} \mathrm{H}-$ $\operatorname{NMR}\left(400 \mathrm{MHz}, \mathrm{CDCl}_{3}\right): 7.42(m, 5 \mathrm{H}) ; 6.43(d, J=2.8,1 \mathrm{H}) ; 6.28(d, J=2.8,1 \mathrm{H}) ; 5.45(d d, J=14.0$, 
RASĀYAN J. Chem.

Vol. 13 | No. 4 |2559-2568| October - December | 2020

2.8, $1 \mathrm{H}) ; 3.81(s, 3 \mathrm{H}) ; 3.01(d d, J=14.0,16.5,1 \mathrm{H}) ; 2.66-2.74(m, 3 \mathrm{H}) ; 1.29(t, 3 \mathrm{H}) .{ }^{13} \mathrm{C}-\mathrm{NMR}(400$ $\left.\mathrm{MHz}, \mathrm{CDCl}_{3}\right)$ : $188.96(\mathrm{C}) ; 173.04(\mathrm{C}) ; 165.57$ (C); 164.33 (C); 152.12 (C); 138.52 (C); $128.98(\mathrm{CH})$; $126.25(4 \mathrm{CH}) ; 108.14(\mathrm{C}) ; 104.86(\mathrm{CH}) ; 99.58(\mathrm{CH}) ; 79.67(\mathrm{CH}) ; 55.92\left(\mathrm{CH}_{3}\right) ; 45.20\left(\mathrm{CH}_{2}\right) ; 27.74\left(\mathrm{CH}_{2}\right)$; $8.82\left(\mathrm{CH}_{3}\right) . \mathrm{m} / z$ for $\left(\mathrm{C}_{19} \mathrm{H}_{18} \mathrm{O}_{5}\right) 326.12$, found 326.1 .

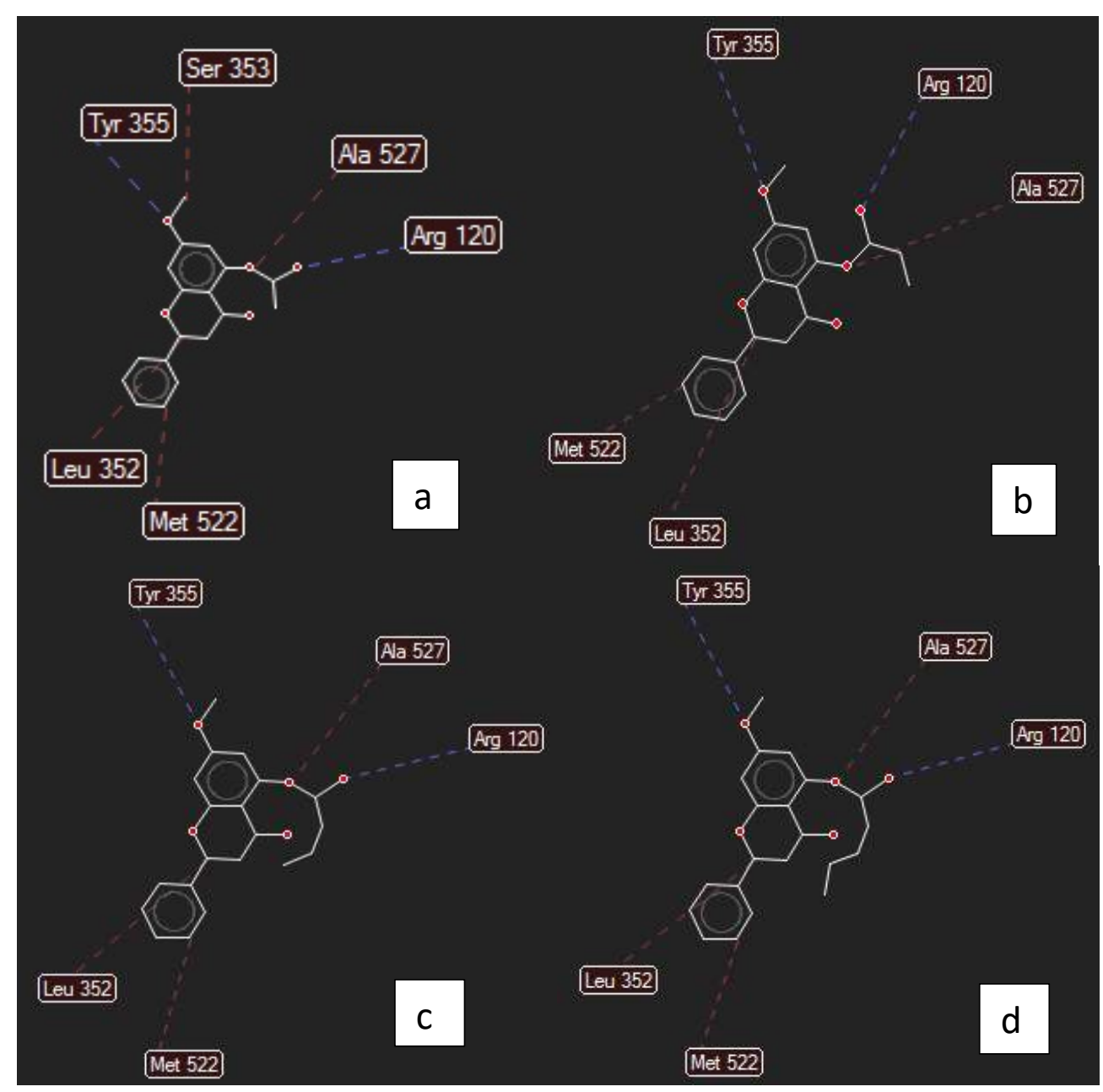

Fig.-3: The Docking Results of 5- $O$-acylpinostrobin Derivatives against COX-2 (PDB: 1PXX). (a) Pinostrobin acetate (2), (b) Pinostrobin propionate (3), (c) Pinostrobin butyrate (4), (d) Pinostrobin pentanoate (5)

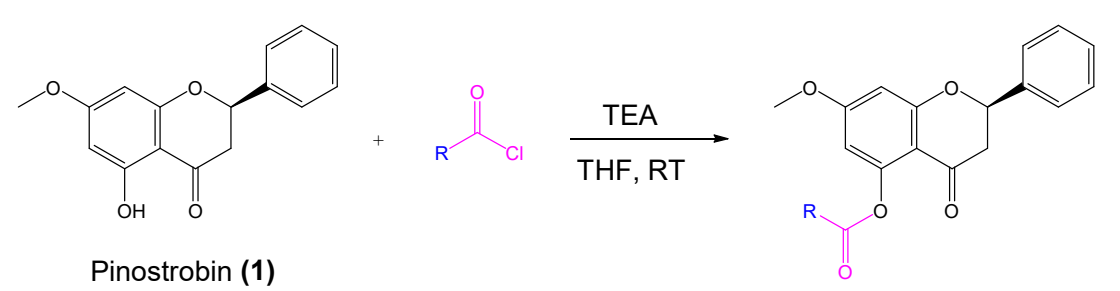

5-O-Acylpinostrobin derivatives

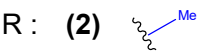
$(84 \%)$
(3) (74\%)
(4) $(69 \%)$
(5)

Fig.-4: Schematic Synthesis of 5-O-acylpinostrobin Derivatives using Schotten-Baumann Reaction

\section{7-methoxy-4-oxo-2-phenylchroman-5-yl butyrate (4)}

This compound was synthesized according to $G P-A$, starting with butyryl chloride. The crude was purified and crystallized to afford the product as a white crystalline with a $69 \%$ yield. M.p. $122-123^{\circ} \mathrm{C} .{ }^{1} \mathrm{H}-\mathrm{NMR}$ 
RASĀYAN J. Chem.

Vol. 13 | No. 4 |2559-2568| October - December | 2020

$\left(400 \mathrm{MHz}, \mathrm{CDCl}_{3}\right): 7.43(m, 5 \mathrm{H}) ; 6.42(d, J=2.4,1 \mathrm{H}) ; 6.28(d, J=2.4,1 \mathrm{H}) ; 5.45(d d, J=14.0,3.2,1$ $\mathrm{H}) ; 3.81(s, 3 \mathrm{H}) ; 3.01(d d, J=16.8,14.0,1 \mathrm{H}) ; 2.66-2.74(m, 3 \mathrm{H}) ; 1.81(m, 2 \mathrm{H}) ; 1.06(t, 3 \mathrm{H}) .{ }^{13} \mathrm{C}-\mathrm{NMR}$ (400 MHz, $\left.\mathrm{CDCl}_{3}\right): 188.92(\mathrm{C}) ; 172.18(\mathrm{C}) ; 165.54(\mathrm{C}) ; 164.32(\mathrm{C}) ; 152.08(\mathrm{C}) ; 138.53(\mathrm{C}) ; 128.98(\mathrm{CH})$; $126.26(4 \mathrm{CH}) ; 108.21(\mathrm{C}) ; 104.91(\mathrm{CH}) ; 99.57(\mathrm{CH}) ; 79.65(\mathrm{CH}) ; 55.92\left(\mathrm{CH}_{3}\right) ; 45.19\left(\mathrm{CH}_{2}\right) ; 36.19\left(\mathrm{CH}_{2}\right)$; $18.08\left(\mathrm{CH}_{2}\right) ; 13.87\left(\mathrm{CH}_{3}\right) . m / z$ for $\left(\mathrm{C}_{20} \mathrm{H}_{20} \mathrm{O}_{5}\right) 340.13$, found 340.1 .

7-methoxy-4-oxo-2-phenylchroman-5-yl pentanoate (5)

This compound was synthesized according to $G P-A$, starting with pentanoyl chloride. The crude was purified and crystallized to afford the product as a white crystalline with a $61 \%$ yield. M.p. $73-74^{\circ} \mathrm{C}$. ${ }^{1} \mathrm{H}-$ $\operatorname{NMR}\left(400 \mathrm{MHz}, \mathrm{CDCl}_{3}\right): 7.42(m, 5 \mathrm{H}) ; 6.43(d, J=2.8,1 \mathrm{H}) ; 6.27(d, J=2.8,1 \mathrm{H}) ; 5.45(d d, J=13.6$, 3.2, $1 \mathrm{H}) ; 3.81(\mathrm{~s}, 3 \mathrm{H}) ; 3.01(d d, J=16.8,13.6,1 \mathrm{H}) ; 2.66-2.74(m, 3 \mathrm{H}) ; 1.78(m, 2 \mathrm{H}) ; 1.47(m, 2 \mathrm{H})$; $0.97(t, 3 \mathrm{H}) .{ }^{13} \mathrm{C}-\mathrm{NMR}\left(400 \mathrm{MHz}, \mathrm{CDCl}_{3}\right): 188.93$ (C); 172.34 (C); 165.55 (C); 164.31 (C); 152.10 (C); $138.53(\mathrm{C}) ; 128.98(\mathrm{CH}) ; 126.25(4 \mathrm{CH}) ; 108.21(\mathrm{C}) ; 104.89(\mathrm{CH}) ; 99.56(\mathrm{CH}) ; 79.65(\mathrm{CH}) ; 55.91\left(\mathrm{CH}_{3}\right)$; $45.20\left(\mathrm{CH}_{2}\right) ; 34.07\left(\mathrm{CH}_{2}\right) ; 26.60\left(\mathrm{CH}_{2}\right) ; 22.44\left(\mathrm{CH}_{2}\right) ; 13.93\left(\mathrm{CH}_{3}\right) . \mathrm{m} / z$ for $\left(\mathrm{C}_{21} \mathrm{H}_{22} \mathrm{O}_{5}\right)$ 354.15, found 354.1.

Full conversions were not achieved in the formation of 5-O-acylpinostrobin derivatives, despite the straightforward reaction. This can be attributed to the presence of an intramolecular hydrogen bond within pinostrobin. The position of phenolic hydrogen in the vicinity of the carbonyl oxygen might result in the formation of the hydrogen bond, thus compromising the reactivity of the hydroxy phenolic group as the nucleophile (Fig.-5).

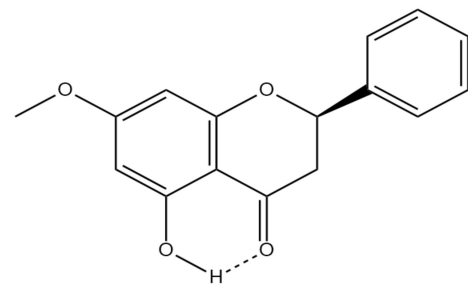

Fig.-5: Intramolecular Hydrogen Bond of Pinostrobin

Nevertheless, moderate to good yields of the compounds (1-5) were obtained (61-84\%) after facile purification through the crystallization method. The purity of the compounds was confirmed through several methods, involving thin layer chromatography, NMR, FTIR, and mass spectroscopy, as it is critical to acquire a highly pure substance before testing it for its biological activity. ${ }^{17}$

\section{Analgesic Evaluation}

The analgesic property of pinostrobin and its derivatives was evaluated using the acetic acid-induced abdominal writhing test. This method has been widely used as a screening tool to evaluate the analgesic or anti-inflammatory properties of substances, where the pain is induced by injecting acetic acid as an irritant into the peritoneal cavity of mice (Mus musculus). The test animals then react by writhing, a characteristic stretching behaviour which is considered as a positive response. ${ }^{18-20}$

Pinostrobin and its derivatives were tested in comparison with CMC-Na $0.5 \%$ as the negative control and the currently marketed analgesic drug sodium diclofenac as the positive control in a single dose. Pinostrobin and its derivatives were given in three doses $(14,28$, and $56 \mathrm{mg} / \mathrm{kg} \mathrm{BW})$. In this method, we observed the percentage of pain inhibition of every compound which can be obtained by the following formula:

$$
\% \text { Pain Inhibition }=\frac{(W c-W t)}{W c} \times 100
$$

Where, $\mathrm{Wc}=$ number of writhes in the negative control group, $\mathrm{Wt}=$ number of writhes in the test group. The results of the writhing test of pinostrobin and its derivatives are shown below(Fig.-6).

The statistical analysis through the calculation of the least significant difference (LSD) shows that there is no significant difference between the analgesic activity of sodium diclofenac and $\mathbf{1}, \mathbf{2}, \mathbf{3}$, and $\mathbf{4}$ compounds at dose $14 \mathrm{mg} / \mathrm{kg} \mathrm{BW}$. However, a significant difference is observed between sodium diclofenac and 
RASĀYAN J. Chem.

Vol. 13 | No. 4 |2559-2568| October - December | 2020

compound $\mathbf{5}$ at the same dose. Besides, the analgesic activity between pinostrobin and its derivatives is statistically significant at the three given doses.

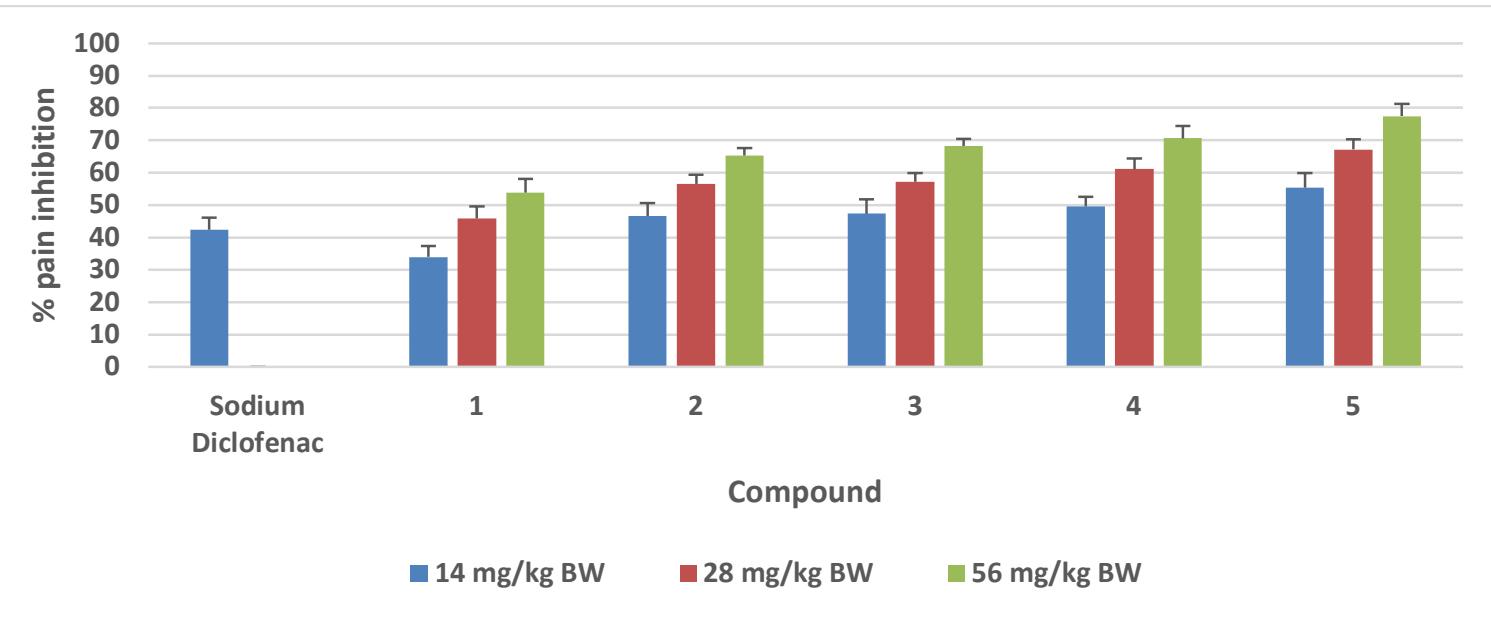

Fig.-6: The Percentage of Pain Inhibition of Pinostrobin and its Four Derivatives in Three given Doses, the Compounds were compared to Sodium Diclofenac as a Positive Control in a Single Lowest Dose

The half-maximal effective dose $\left(\mathrm{ED}_{50}\right)$ of each compound was determined statistically using SPSS software. $\mathrm{ED}_{50}$ is defined as a dose of a substance that produces a specific effect in $50 \%$ of the population under stated conditions. ${ }^{21}$ The $\mathrm{ED}_{50}$ and $\log 1 / \mathrm{ED}_{50}$ values of pinostrobin and its derivatives are shown in Table-1 below.

\begin{tabular}{|c|c|c|}
\hline Compound & $\begin{array}{c}\mathrm{ED}_{50} \\
(\mathrm{mg} / \mathrm{kg} \mathrm{BW})\end{array}$ & $\begin{array}{l}\log \left(1 / \mathrm{ED}_{50}\right) \\
(\mathrm{mg} / \mathrm{kg} \mathrm{BW})\end{array}$ \\
\hline Pinostrobin (1) & 41.10 & -1.61 \\
\hline Pinostrobin acetate (2) & 17.80 & -1.25 \\
\hline Pinostrobin propionate (3) & 16.92 & -1.23 \\
\hline Pinostrobin butyrate (4) & 14.17 & -1.15 \\
\hline Pinostrobin pentanoate (5) & 10.37 & -1.02 \\
\hline
\end{tabular}

Compound 5 displays the best analgesic property with an $\mathrm{ED}_{50}$ value of $10.37 \mathrm{mg} / \mathrm{kg} \mathrm{BW}$, while pinostrobin shows a poor activity of pain inhibition with an $\mathrm{ED}_{50}$ value of $41.10 \mathrm{mg} / \mathrm{kg}$ BW. More importantly, the analgesic potency of 5-O-acylpinostrobin derivatives increases with the increasing alkyl chain length. Furthermore, we determined the quantitative structure-activity relationship (QSAR) of pinostrobin and its derivatives through the physicochemical properties, in silico test (rerank score), and in vivo test $\left(\log 1 / \mathrm{ED}_{50}\right)$ are shown in Table-2 below.

Table-2: Physicochemical Properties of Pinostrobin and its Derivatives, in silico and in vivo Analgesic Activity Tests as Parameters in QSAR Determination

\begin{tabular}{c|c|c|c|c|c|c}
\hline Compound & Log P & $\log \mathrm{P}^{2}$ & $\begin{array}{c}\mathrm{E}_{\text {total }} \\
(\mathrm{kcal} / \mathrm{mol})\end{array}$ & $\begin{array}{c}\text { MR } \\
\left(\mathrm{m}^{3} / \mathrm{mol}\right)\end{array}$ & $\begin{array}{c}\text { Rerank Score } \\
(\mathrm{kcal} / \mathrm{mol})\end{array}$ & $\begin{array}{c}\text { Log(1/ED } \\
(\mathrm{mg} / \mathrm{kg} \mathrm{BW})\end{array}$ \\
\hline Pinostrobin (1) & 2.28 & 5.20 & 46.2108 & 75.29 & -87.18 & -1.61 \\
\hline Pinostrobin acetate (2) & 2.26 & 5.11 & 56.8544 & 84.68 & -90.27 & -1.25 \\
\hline Pinostrobin propionate (3) & 2.91 & 8.47 & 56.5023 & 89.42 & -98.61 & -1.23 \\
\hline Pinostrobin butyrate (4) & 3.33 & 11.09 & 56.3453 & 94.02 & -102.70 & -1.15 \\
\hline Pinostrobin pentanoate (5) & 3.75 & 14.06 & 56.2704 & 98.62 & -107.59 & -1.02 \\
\hline
\end{tabular}


RASĀYAN J. Chem.

Vol. 13 | No. 4 |2559-2568| October - December | 2020

QSAR analysis of 5-O-acylpinostrobin derivatives was performed using linear and nonlinear regression analysis by SPSS software. Five QSAR equations are shown in table 3 below.

Table-3: Five QSAR Equations of 5-O-acylpinostrobin Derivatives involving Physicochemical Properties, in silico and in vivo Analgesic Activity Tests as Parameters

\begin{tabular}{c|c|c|c|c|c|c}
\hline No & QSAR Equation & $\mathrm{n}$ & $\mathrm{r}$ & $\mathrm{SE}$ & $\mathrm{F}$ & Sig. \\
\hline 1 & $\log \left(1 / \mathrm{ED}_{50}\right)=0.272 \log \mathrm{P}-2.041$ & 5 & -0.806 & 0.150 & 5.580 & 0.099 \\
\hline 2 & $\log \left(1 / \mathrm{ED}_{50}\right)=0.001 \log \mathrm{P}^{2}+0.268 \log \mathrm{P}-2.036$ & 5 & 0.806 & 0.081 & 1.860 & 0.350 \\
\hline 3 & $\log \left(1 / \mathrm{ED}_{50}\right)=0.043 \mathrm{E}_{\text {total }}-3.573$ & 5 & 0.894 & 0.114 & 11.944 & 0.041 \\
\hline 4 & $\log \left(1 / \mathrm{ED}_{50}\right)=0.024 \mathrm{MR}-3.348$ & 5 & 0.970 & 0.062 & 47.544 & 0.006 \\
\hline 5 & $\log \left(1 / \mathrm{ED}_{50}\right)=-0.023 R S-3.468$ & 5 & 0.881 & 0.120 & 10.443 & 0.048 \\
\hline
\end{tabular}

In equations 1 and 2, no linear and nonlinear correlation was observed between lipophilicity $(\log P)$ of the compounds and their analgesic activity, while in equations 3, 4, and 5 there is a linear and nonlinear correlation. Equation 3 is a relationship between the electronic parameter $\left(\mathrm{E}_{\text {total }}\right)$ and analgesic activity of pinostrobin and its four derivatives, the higher the $\mathrm{E}_{\text {total }}$ of the compound, the more potent the analgesic activity. Equation 4 suggests the linear correlation between the steric property (MR) and analgesic activity of the tested compounds, the higher the value of MR, the more potent the analgesic activity. Equation 5 shows there is a linear correlation between the ligand-receptor affinity (rerank score) and the in vivo analgesic activity, the lower the rerank score, the lower the energy needed to stabilize the bond between the ligand and the receptor, thus the more potent the analgesic activity.

In this study, a QSAR equation involving the steric parameter is proposed as follows:

$$
\begin{gathered}
\log \left(1 / \mathrm{ED}_{50}\right)=0.024 \mathrm{MR}-3.348 \\
(\mathrm{n}=5 ; \mathrm{r}=0.970 ; \mathrm{F}=47.544 ; \text { sig. }=0.006 ; \mathrm{SE}=0.062)
\end{gathered}
$$

The equation can be a reference in the prediction of the analgesic activity of 5-O-acylpinostrobin derivatives with different side chain by incorporating the steric parameter (MR) into the equation.

\section{CONCLUSION}

We report on a successful molecular modification of pinostrobin which resulted in an improvement of analgesic activity. Four derivatives of 5-O-acylpinostrobin were synthesized using a straightforward Schotten-Baumann reaction, with moderate to good yields (61-84\%). The acetic acid-induced writhing test resulted in compound $\mathbf{5}$ as the most potent analgesic $\left(\mathrm{ED}_{50}=10.37 \mathrm{mg} / \mathrm{kg} \mathrm{BW}\right)$, showing a prospect for a new drug candidate. This outcome is consistent with the in silico studies before the synthesis that can be utilized to predict the biological activity, ${ }^{22-23}$ in which it suggests the increasing analgesic activity as the side alkyl chain extended. Besides, a QSAR equation is proposed involving a steric parameter (MR), which constitutes a predictive tool for future optimization.

\section{ACKNOWLEDGEMENT}

This research was supported by Faculty Research Grand supported by the Faculty of Pharmacy Universitas Airlangga, Surabaya.

\section{REFERENCES}

1. (IASP) (International Association for the Study of Pain) \& (EFIC) (European Federation of IASP Chapters), Unrelieved Pain is a Major Global Healthcare Problem, Amazon, S3, 1(2004),

2. B. J. Sessle, Pain Research and Management, 16(6), 416(2011), DOI:10.1155/2011/513423

3. L. R. Watkins, E. D. Milligan, and S. F. Maier, Advances in Experimental Medicine and Biology, 521, 1(2003).

4. P. O. Osadebe and F. B. C. Okoye, Journal of Ethnopharmacology, 89(1),19(2003), DOI: 10.1016/S0378-8741(03)00195-8

5. C. Sostres, C. J. Gargallo, M. T. Arroyo, and A. Lanas, Clinical Gastroenterology 24(2), 121(2010). 
RASĀYAN J. Chem.

Vol. 13 | No. 4 |2559-2568| October - December | 2020

6. J. L. Wallace, Physiological Reviews, 88(4), 1547(2008), DOI:10.1152/physrev.00004.2008

7. C. Bombardier et al., The New England Journal of Medicine, 343, 1520(2000), DOI: 10.1056/nejm200011233432103

8. T. J. Schnitzer et al.,The Lancet, 364, 665(2004), DOI:10.1016/S0140-6736(04)16893-1

9. M. J. Hochmair et al., Future Oncology, 14, 2861(2018), DOI:10.2217/fon-2019-0346

10. Purwantiningsih, N. Jannah, and D. U. C. Rahayu, Rasayan Journal of Chemistry, 13(1), 322(2020), DOI: $10.31788 /$ RJC.2020.1315484

11. A. Chahyadi, R. Hartati, K. R. Wirasutisna, and Elfahmi, Procedia Chemistry, 13, 13(2014), DOI: 10.1016/j.proche.2014.12.003

12. N. K. Patel, G. Jaiswal, and K. K. Bhutani, Natural Product Research, 30(18), 2017(2016), DOI: 10.1080/14786419.2015.1107556

13. I. Gómez-Betancur, D. Benjumea, A. Patiño, N. Jiménez, and E. Osorio, Journal of Ethnopharmacology, 155(3), 1609(2014), DOI:10.1016/j.jep.2014.08.002

14. D. Wu, M. G. Nair, and D. L. DeWitt, Journal of Agricultural and Food Chemistry, 50(4), 701(2002). DOI: $10.1021 / \mathrm{jf010963x}$

15. N. A. Peerzade, S. Y. Jadhav, and R. B. Bhosale, Rasayan Journal of Chemistry, 13(3), 1401(2020), DOI: $10.31788 /$ RJC.2020.1335637

16. C. Zhao et al., Separation and Purification Technology, 133, 168(2014), DOI: 10.1016/j.seppur.2014.06.056

17. G. F. Pauli et al., Journal of Medicinal Chemistry, 57(22), 9220(2014), DOI:10.1021/jm500734a

18. S. Singh, and D. K. Majumdar, Pharmaceutical Biology, 33, 188(1995), DOI: $10.3109 / 13880209509065361$

19. A. Burke, E. Smyth, and G. A. Fitzgerald, Analgesic - Antipyretic Agents, Pharmacotherapy of Goat. in Goodman and Gilman's The Pharmacological Basis of Therapeutics, $11^{\text {th }}$ edition. McGraw-Hill, New York, 2006.

20. D. Mishra, G. Ghosh, P. Sudhir Kumar, and P. K. Panda, Asian Journal of Pharmaceutical and Clinical Research, 4, 78(2011).

21. K. K. Rozman, J. Doull, and W. J. Hayes, Dose and Time Determining, and Other Factors Influencing, Toxicity, in Hayes' Handbook of Pesticide Toxicology $3^{\text {rd }}$ edition, pp. 3(2010), DOI:10.1016/B978-012-374367-1.00001-X

22. D. Kesuma, A. L. Nasyanka, M. Rudyanto, and B. T. Purwanto, Rasayan Journal of Chemistry, 13(3), 1914(2020), DOI: 10.31788/RJC.2020.1335694

23. S. Hardjono, T. Widiandani, B.T. Purwanto, A. L. Nasyanka, Research Journal of Pharmacy and Technology, 12(5), 2160(2019), DOI: 10.5958/0974-360X.2019.00359.7

[RJC-5749/2020] 